\title{
Wilting Bermudagrass Improves Forage Silage Quality and Cattle Performance 1
}

William E. Kunkle ${ }^{2}$

Bermudagrass has low levels of sugars that are fermented to lactic and other acids during ensiling. Wilting has been shown to improve the fermentation and the feeding value when levels of sugar are low. The effects of wilting on bermudagrass harvested as round bale silage were investigated in two trials. The round bale silage was compared to similar bermudagrass harvested as round baled hay.

Bermudagrass was harvested after 5 to 6 weeks of regrowth in 1988 and 6 to 7 weeks of regrowth in 1989. The treatments included baling immediately after cutting (unwilted), baling after 1 to 2 hours of wilt, baling after 2 to 4 hours of wilt or field curing and harvesting as hay. Forage was baled with a New Holland 848 baler in bales 4 feet wide and 4.5 feet in diameter. The high-moisture forage was wrapped with four layers of stretch wrap plastic and stored under trees. Hay was stored in a barn. After 4 to 8 months of storage, the forage was fed to heifers in round-bale feeders and wasted forage was removed and weighed. Individual bales were identified and weighed at harvest and at feeding. Each treatment was fed to two groups of 10 growing heifers averaging 550 pounds in 1988 and 520 pounds in 1989. Bermudagrass forage intake and heifer weight gains and height changes were determined in an 87-day feeding trial in 1988 and a 98-day feeding trial in 1989.

In two trials in which wilted bermudagrass was compared to unwilted forage, wilting 2 to 4 hours had the following effects:

1. Forage moisture was reduced 20 percentage units from 71 to $51 \%$.

2. Bale weights were reduced by 100 pounds per bale from 1,450 to 1,350 pounds.

3. Forage dry matter increased 200 pounds per bale from 420 to 620 pounds.

4. Number of bales and plastic and wrapping costs were reduced by $30 \%$.

5. Storage losses were reduced 3.7 percentage units from 12.5 to $8.8 \%$ of the dry matter lost during storage.

6. Feeding losses were increased 6.7 percentage units from 10.1 to 16.8 of the dry matter wasted at feeding. Molding of forage due to holes in the

1. This document is AN146, one of a series of the Department of Animal Sciences, Florida Cooperative Extension Service, UF/IFAS. Published October 2003. Please visit the EDIS Web Site at http://edis.ifas.ufl.edu.

2. William E. Kunkle, former Professor and Extension Beef Specialist in the Department of Animal Sciences, Florida Cooperative Extension Service,

UF/IFAS, Gainesville, FL, 32611.

The use of trade names in this publication is solely for the purpose of providing specific information. UF/IFAS does not guarantee or warranty the products named, and references to them in this publication do not signify our approval to the exclusion of other products of suitable composition.

The Institute of Food and Agricultural Sciences (IFAS) is an Equal Employment Opportunity - Affirmative Action Employer authorized to provide research, educational information and other services only to individuals and institutions that function without regard to race, creed, color, religion, age, disability, sex, sexual orientation, marital status, national origin, political opinions or affiliations. For information on obtaining other extension publications, contact your county Cooperative Extension Service office. Florida Cooperative Extension Service / Institute of Food and Agricultural Sciences / University of Florida / Larry R. Arrington, Interim Dean 
plastic contributed to wasted forage and the losses were higher in drier forage.

7. Silage quality was improved and resulted in a $13 \%$ increase in intake from 1.67 to $1.89 \%$ of body weight, daily gains were increased .4 pounds from -.15 to +.25 pounds, and growth in height was increased .48 inches over 3 months from .43 to .91 inches growth in height.

Forage wilted to 50 to $60 \%$ moisture resulted in similar intakes and animal performance compared to forage harvested as hay, but storage and feeding losses were 9 percentage units higher for the silage compared to hay. 
Table 1. Effect of wilting bermudagrass on forage characteristics, bale weight, feed and storage losses, and intake and performance of growing cattle. ${ }^{a}$

\begin{tabular}{|c|c|c|c|c|}
\hline \multirow[b]{2}{*}{ Item } & \multicolumn{3}{|c|}{ Wilting time, hours } & \multirow[b]{2}{*}{ Hay } \\
\hline & None & $1-2$ & $2-4$ & \\
\hline \multicolumn{5}{|l|}{ Forage moisture, \% } \\
\hline 1988 & 73.9 & 63.3 & 52.2 & 13.3 \\
\hline 1989 & $\underline{69.1}$ & $\underline{60.8}$ & $\underline{54.3}$ & $\underline{25.5}$ \\
\hline Average & 71.5 & 62.1 & 53.3 & 19.4 \\
\hline \multicolumn{5}{|c|}{ Forage dry matter, \% } \\
\hline 1988 & 26.1 & 36.7 & 47.8 & 86.7 \\
\hline 1989 & $\underline{30.9}$ & 39.2 & 45.7 & $\underline{74.5}$ \\
\hline Average & 28.5 & $\overline{37.9}$ & 46.8 & 80.6 \\
\hline \multicolumn{5}{|l|}{ Wet bale weight, lb } \\
\hline 1988 & 1,362 & 1,405 & 1,273 & 622 \\
\hline 1989 & $\underline{1,545}$ & $\underline{1,445}$ & $\underline{1,415}$ & $\underline{800}$ \\
\hline Average & $\overline{1,454}$ & $\overline{1,425}$ & $\overline{1,344}$ & $\overline{711}$ \\
\hline \multicolumn{5}{|l|}{ Dry bale weight, lb } \\
\hline 1988 & 357 & 515 & 608 & 536 \\
\hline 1989 & $\underline{477}$ & $\underline{565}$ & $\underline{635}$ & $\underline{595}$ \\
\hline Average & 417 & 540 & 622 & 566 \\
\hline \multicolumn{5}{|c|}{ Storage losses, \% DM } \\
\hline 1988 & 14.7 & 13.3 & 9.4 & 3.0 \\
\hline 1989 & 10.2 & $\underline{9.7}$ & 8.1 & $\underline{2.9}$ \\
\hline Average & $\overline{12.5}$ & $\overline{11.5}$ & $\overline{8.8}$ & $\overline{3.0}$ \\
\hline \multicolumn{5}{|c|}{ Feeding losses, \% dry matter } \\
\hline 1988 & 8.7 & 9.2 & 13.0 & 7.2 \\
\hline 1989 & $\underline{11.5}$ & $\underline{16.2}$ & $\underline{20.5}$ & $\underline{17.7}$ \\
\hline Average & $\overline{10.1}$ & $\overline{12.7}$ & $\overline{16.8}$ & $\overline{12.5}$ \\
\hline \multicolumn{5}{|c|}{ Dry matter intake, Ib/day } \\
\hline 1988 & 9.2 & 10.2 & 10.9 & 11.0 \\
\hline 1989 & $\underline{8.0}$ & $\underline{8.9}$ & $\underline{9.5}$ & $\underline{8.7}$ \\
\hline Average & 8.6 & 9.6 & $\overline{10.2}$ & $\overline{9.9}$ \\
\hline \multicolumn{5}{|c|}{ Dry matter intake, $\%$ body weight } \\
\hline 1988 & 1.67 & 1.84 & 1.96 & 1.88 \\
\hline 1989 & $\underline{1.66}$ & $\underline{1.78}$ & $\underline{1.81}$ & $\underline{1.65}$ \\
\hline Average & $\overline{1.67}$ & $\overline{1.81}$ & $\overline{1.89}$ & 1.77 \\
\hline \multicolumn{5}{|l|}{ Daily gain, lb/head } \\
\hline 1988 & -.07 & .15 & .35 & .53 \\
\hline 1989 & -.22 & $\underline{-.13}$ & .15 & .04 \\
\hline Average & -.15 & +.01 & +.25 & +.29 \\
\hline \multicolumn{5}{|c|}{ Height increase, inches } \\
\hline 1988 (87 days) & .19 & .84 & .86 & 1.00 \\
\hline 1989 (98 days) & .66 & .97 & .95 & $\underline{1.12}$ \\
\hline Average & .43 & .91 & .91 & 1.06 \\
\hline
\end{tabular}

\footnotetext{
${ }^{a}$ Regrowth was 5-6 weeks in 1988 and 6-7 weeks in 1989.
} 